\title{
Molecular characterization and clonal diversity of methicillin-susceptible Staphylococcus aureus in milk of cows with mastitis in Brazil
}

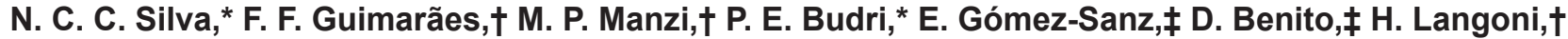 \\ V. L. M. Rall, ${ }^{\star}$ and C. Torres $\ddagger^{1}$ \\ *Department of Microbiology and Immunology, and \\ †Department of Hygiene Veterinary and Public Health, Universidade Estadual Paulista (UNESP), Botucatu 18.618-970, SP, Brazil \\ łDepartment of Food and Agriculture, University of La Rioja, 26006 Logroño, Spain
}

\section{ABSTRACT}

Mastitis is an important disease for the dairy industry worldwide, causing economic losses and reducing milk quality and production. Staphylococcus aureus is a worldwide agent of this intramammary infection, which also causes foodborne diseases. The objective of this study was to determine the frequency of methicillinsusceptible Staphylococcus aureus (MSSA) isolates in milk of mastitis cows in Brazil and to analyze the genetic lineages and the content of antimicrobial resistance genes and virulence factors among these isolates. Fifty-six MSSA isolates were recovered from 1,484 milk samples (positive for the California mastitis test) of 518 cows from 11 different farms in Brazil (representing $51 \%$ of total Staph. aureus obtained), and they were further characterized. Methicillin-susceptible Staphylococcus aureus were isolated from $3.7 \%$ of California mastitis test-positive tested milk samples and from $6.2 \%$ of tested mastitic cows. Methicillin-susceptible Staphylococcus aureus isolates were characterized by spa typing, agr typing, and multilocus sequence typing, and resistance and virulence traits were investigated by PCR. Seven spa types were identified among MSSA (\% of isolates): t127 (44.6), t605 (37.5), t002, t1784, t2066 (1.8), and 2 new ones: t10856 (10.7) and t10852 (1.8). Five distinct sequence types (ST) were detected (\% of isolates): ST1 (46.4), ST126 (37.5), ST133 (10.7), ST5 (3.6), and a novel ST registered as ST2493 (1.8). Resistances were detected for streptomycin, chloramphenicol, and tetracycline. One strain contained the chloramphenicol resistance gene (fexA; included within transposon Tn558) and 3 strains contained the tetracycline resistance gene $[$ tet $(\mathrm{K})]$. Methicillin-susceptible Staphylococcus aureus strains were susceptible to most of the antibiotics studied and lacked the virulence genes of Panton-Valentine leukocidin (lukF/S-PV), toxic shock syndrome toxin $1(t s t)$, exfoliative toxin A

Received February 21, 2013.

Accepted July 22, 2013.

${ }^{1}$ Corresponding author: carmen.torres@unirioja.es (eta), and exfoliative toxin B (etb), as well as the genes of the immune evasion cluster. Methicillin-susceptible Staphylococcus aureus isolates were detected in a relatively low proportion of cows with mastitis $(6.2 \%)$ and recovered isolates presented high diversity of genetic lineages, with $\mathrm{CC} 1$ and $\mathrm{CC} 126$ the predominant clonal complexes, and CC133 also being detected. Larger epidemiological studies with molecular characterization of isolates are required to deepen the knowledge on the circulating genetic lineages among the cow population with mastitis.

Key words: Staphylococcus aureus, methicillin susceptibility, spa typing, mastitis

\section{INTRODUCTION}

Milk production in Brazil is one of the most important branches of the Brazilian agribusiness and the country is the sixth leading producer of milk (Klein et al., 2012). Dairy cow mastitis is the most important disease in the dairy industry worldwide, and it is associated with pain and reduced well-being of affected animals (Halasa et al., 2007). Mastitis causes economic losses due to reduced milk production, milk discard, premature slaughter, and antibiotic usage (McDougall et al., 2009).

In Brazil, several studies have reported the isolation of Staphylococcus aureus in milk samples from cows with mastitis (Zafalon et al. 2007; Santos et al. 2008; Klein et al., 2012); however, studies related to molecular characterization of Staph. aureus from these types of milk samples are scarce. This microorganism is one of the most important etiological agents of mastitis, which is of concern for humans and livestock (Capurro et al. 2010). Staphylococcus aureus can produce a wide range of extracellular toxins and virulence factors such as Panton-Valentine leukocidin (PVL), toxic shock syndrome toxin (TSST), and several exfoliatins and enterotoxins, which represent a risk for humans and animals, being associated with severe infections (Jarraud et al., 2002; Francis et al., 2005). 
Staphylococcus aureus can acquire methicillin resistance (MRSA) due to the acquisition of the mecA gene. Methicillin resistance represents an important therapeutic problem when implicated in human or animal infections, and numerous studies have focused on the characterization of these isolates. Nevertheless, the interest on methicillin-susceptible Staph. aureus (MSSA) has increased in recent years, given that they can also be implicated in important infections and may help to explain the appearance and evolution of the different and successful MRSA lineages. Few data exist in the circulating genetic lineages of MSSA in foodproducing animals or in derived food products, as in the case of milk.

Coagulase-positive and coagulase-negative staphylococci were recovered in a previous study from milk of cows with mastitis from 10 farms in Brazil and enterotoxin genes were studied in these isolates (de Freitas Guimarães et al., 2013). The present work focused on the molecular characterization of MSSA isolates recovered in milk of mastitic cows in Brazil, analyzing the genetic lineages of the isolates as well as their content in antimicrobial resistance genes and in specific virulence genes, including, among others, the MSSA isolates obtained in the previous study (de Freitas Guimarães et al., 2013).

\section{MATERIALS AND METHODS}

\section{Samples and Bacterial Isolates}

A total of 4,684 milk samples from 1,171 cows (from the 4 teats) from 11 different farms in the state of São Paulo, Brazil, were evaluated for mastitis detection. The methodology and interpretation criteria used for diagnosis of clinical and subclinical mastitis were based on examination of animals before each milking by the California mastitis test (CMT; Schalm and Noorlander, 1957). From these samples, 1,484 of them, obtained from 518 cows, were CMT positive and were studied for staphylococci detection. The CMT-positive samples were plated on blood agar plates (Oxoid Brasil Ltda, São Paulo, Brazil) and incubated under aerobic conditions at $37^{\circ} \mathrm{C}$, and readings were performed after 24,48 , and $72 \mathrm{~h}$ of incubation. Identification of Staph. aureus was based on colony morphology, Gram staining, and catalase, coagulase, and DNase activities (Koneman et al., 2008). Molecular identification was performed by a multiplex PCR that also allows the discrimination of MSSA and MRSA by amplification of the speciesspecific staphylococcal nuclease $(n u c)$ gene and the staphylococcal methicillin-resistance genetic determinant (mecA; CRL-AR, 2009). One MSSA isolate per positive mammary gland was characterized. The MSSA isolates from 10 of the studied farms $(\mathrm{n}=50)$ were obtained in a previous study (de Freitas Guimarães et al., 2013), and those from 1 additional farm $(\mathrm{n}=6)$ were obtained in the present study; all 56 MSSA isolates of the 11 farms were characterized in the present study.

\section{Molecular Typing and Clonal Relatedness of MSSA Isolates}

All MSSA isolates were characterized by spa gene typing (http://spaserver.ridom.de) and agr allotype (Shopsin et al., 2003) by specific PCR. Multilocus sequence typing was performed as previously described (http://www.mlst.net) on 1 representative strain per spa type. Pulsed-field gel electrophoresis (PFGE) of genomic DNA, previously digested with the macrorestriction $S m a$ I enzyme, was performed on 1 strain per spa type per cow. Pulsed-field gel electrophoresis band profiles were compared according to previously reported criteria (Tenover et al., 1995).

\section{Antimicrobial Susceptibility Testing and Detection of Resistance Genes}

Antimicrobial susceptibility testing to oxacillin, cefoxitin, tetracycline, erythromycin, clindamycin, gentamicin, tobramycin, streptomycin, trimethoprimsulfamethoxazole, ciprofloxacin, and chloramphenicol was performed by the disk-diffusion agar method in accordance with the Clinical and Laboratory Standards Institute recommendations (CLSI, 2012). Detection of antimicrobial resistance genes was investigated in resistant isolates by specific PCR (Table 1). Positive and negative controls from the collection of the University of La Rioja (Logroño, Spain) were used in each PCR assay.

\section{Virulence Factors and Immune Evasion Cluster Genes}

The presence of the genetic determinants of PantonValentine leukocidin (lukF/S-PV), toxic shock syndrome toxin 1 (tst), and exfoliative toxin A (eta) and B (etb) was analyzed by PCR (Lina et al., 1999; Jarraud et al., 2002). The presence of the human-associated immune evasion cluster (IEC) genes ( $s c n, c h p, s a k, h l b$, sea, and sep), which were enclosed within the $\varphi 3$ bacteriophage, was determined as previously recommended (van Wamel et al., 2006).

\section{RESULTS}

Staphylococcus aureus isolates were recovered from 97 of the 1,484 CMT-positive milk samples tested (6.5\%) 
Table 1. Primers used for PCR detection of antibiotic resistance genes and the transposon Tn 558

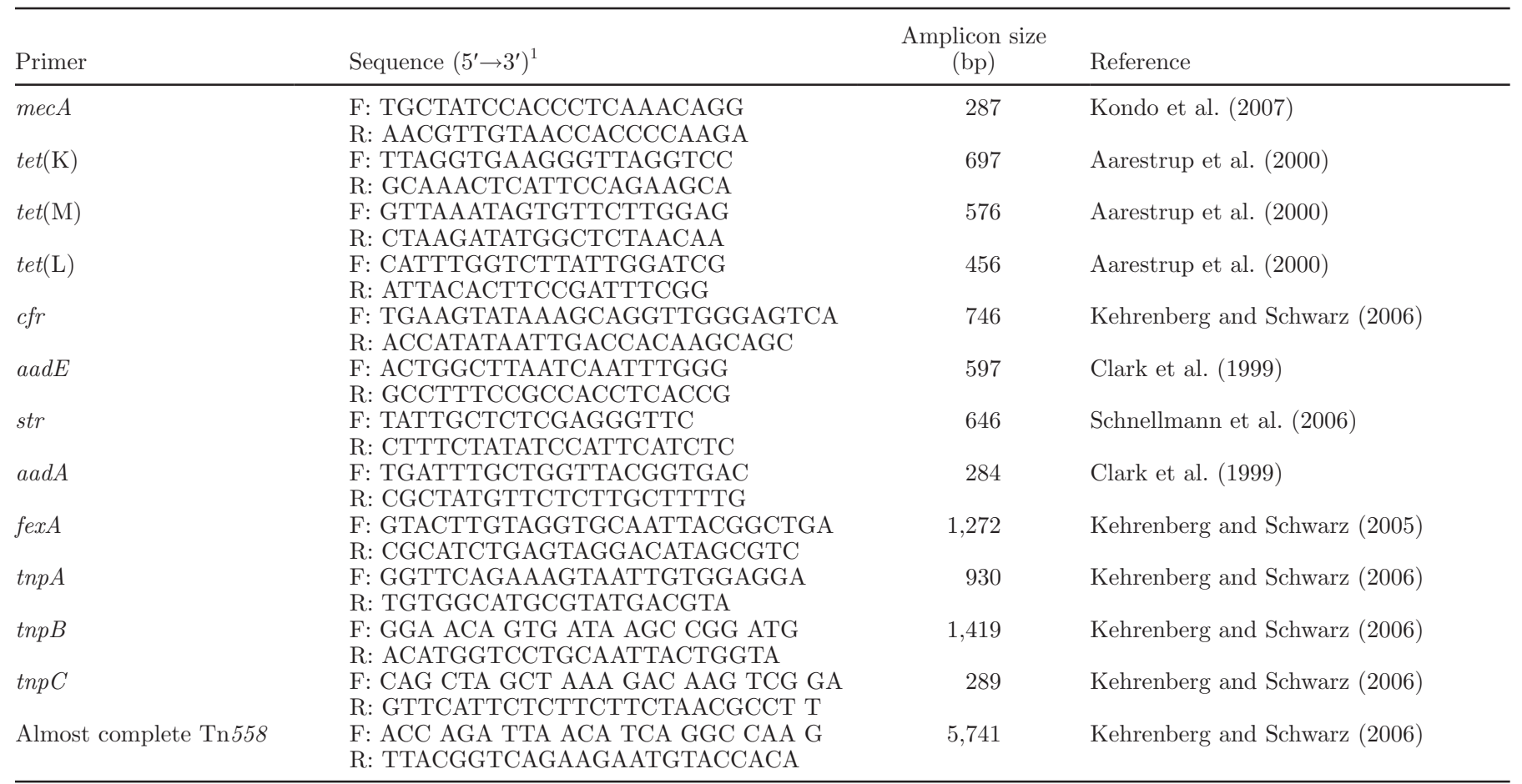

${ }^{1} \mathrm{~F}=$ forward $\mathrm{R}=$ reverse.

and were obtained in $10.2 \%$ of cows tested with mastitis. Among these, 56 isolates were MSSA (57.7\% of total Staph. aureus), obtained from $3.7 \%$ of the tested CMT-positive milk samples and from $6.2 \%$ of mastitic cows (32 animals), and they were further characterized in this study ( 1 isolate per positive sample). Among the 32 cows positive for MSSA detection, 17 of them presented this microorganism in milk samples of more than 1 teat $(12$ animals with 2 positive teats, 3 animals with 3 positive teats, and 2 animals with 4 positive teats).

\section{Molecular Typing of MSSA Isolates}

Two new spa types were identified among 7 of the 56 tested MSSA isolates: (1) 1 isolate presented the spa type t10852 and was also ascribed to the novel sequence type (ST)2493, enclosed within clonal complex (CC)1, and (2) 6 isolates presented the spa type t10856 and were ascribed to ST133 (CC133). The other spa/ST/CC types detected among the remaining 49 MSSA isolates were as follows (number of isolates in parentheses): t605/ST126/CC126 (25), t127/ST1/CC1 (21), t002/ST5/CC5 (1), t1784/ST1/CC1 (1), and t2066/ST5/CC5 (1). The following agr allotypes were obtained (number of isolates in parentheses): agr-I (6), $a g r$-II (23), and $a g r$-III (27), whereas agr-IV was not found (Table 2).
The MSSA isolates recovered from different teats presented similar genetic characteristics (spa/ST/CC) in 16 of the 17 animals that carried MSSA in more than 1 teat. The SmaI PFGE performed with 29 representative MSSA isolates (1 per spa type and per cow) revealed that isolates that belonged to the same spa type presented identical or closely related patterns (less than 3 bands of difference; for example, patterns A1-A2-A3; Table 2), whereas those with a distinct spa type exhibited unrelated PFGE profiles (more than 6 DNA bands of difference; for example, patterns A, B, or C; Table 2).

\section{Antimicrobial Resistance, Toxin Genes, and IEC Profile of MSSA Isolates}

Few resistances were detected among our MSSA isolates: streptomycin (50\%), and chloramphenicol and tetracycline (3.5\%). Three tetracycline-resistant isolates harbored the tetracycline-efflux protein (tetK) gene and 1 chloramphenicol-resistant isolate the florfenicolchloramphenicol exporter gene (fexA; Table 3$)$. The possible inclusion of the fexA gene within the transposon Tn558 was investigated (Kehrenberg and Schwarz, 2006), revealing the presence of the transposase gene (tnpA, tnpB, and tnpC) and orf138, characteristics of the conserved transposon. In addition, circular intermediates were detected, indicating functional activity. 
Table 2. Number and characteristics of methicillin-susceptible Staphylococcus aureus (MSSA) isolates investigated and number of positive cows

\begin{tabular}{|c|c|c|c|c|c|}
\hline $\begin{array}{l}\text { No. of } \\
\text { MSSA isolates }\end{array}$ & $\begin{array}{l}\text { No. of } \\
\text { animals }\end{array}$ & agr type ${ }^{1}$ & spa type ${ }^{2}$ & $\mathrm{ST} / \mathrm{CC}^{3}$ & $\begin{array}{l}\text { PFGE pattern } \\
\text { (no. of isolates) }\end{array}$ \\
\hline 25 & 15 & III & t127 & ST1/CC1 & A1 (12), A2 (2), A3 (1) \\
\hline 21 & 10 & II & t605 & ST126/CC126 & $\mathrm{B} 1(5), \mathrm{B} 2(3), \mathrm{B} 3(2)$ \\
\hline 6 & 4 & $\mathrm{I}$ & $\mathrm{t} 10856_{(\text {new) }}$ & ST133/CC133 & $\mathrm{C} 1(3), \mathrm{C} 2(1)$ \\
\hline 1 & 1 & III & $\mathrm{t} 10852_{\text {(new) }}$ & $\mathrm{ST} 2493_{\text {(new) }} / \mathrm{CC} 1$ & - \\
\hline 1 & 1 & I & $\mathrm{t} 1784$ & $\mathrm{ST} 1 / \mathrm{CC} 1$ & - \\
\hline 1 & 1 & II & t002 & ST5/CC5 & - \\
\hline 1 & 1 & II & t2066 & ST5/CC5 & - \\
\hline
\end{tabular}

${ }^{1}$ agr $=$ accessory gene regulator.

${ }^{2}$ spa $=$ Staphylococcus protein A-encoding gene.

${ }^{3} \mathrm{ST}=$ sequence type $\mathrm{CC}=$ clonal complex. Performed in 1 strain per spa type.

${ }^{4} \mathrm{PFGE}=$ pulsed-field gel electrophoresis .

No streptomycin resistance genes were identified in the streptomycin-resistant staphylococci. All MSSA isolates were negative for the tested toxin genes $(l u k F / S-P V$, $t s t$, eta, and $e t b)$ as well as for the IEC genes (scn, chp, $s a k, h l b$, sea, and sep).

\section{DISCUSSION}

The occurrence of MSSA isolates among milk samples of cows with mastitis detected in our study was relatively low ( $6.2 \%$ of cows with mastitis tested). Nevertheless, other staphylococci (both coagulase-positive and coagulase-negative) were present in these samples (up to $20 \%$ of CMT-positive samples contained staphylococci), as has been previously reported (de Freitas Guimarães et al., 2013), and could be implicated in clinical or subclinical mastitis, with Staph. aureus the most important species among coagulase-positive staphylococci. Milk contamination with Staph. aureus is of concern because it puts at risk people working on the farm. Moreover, contaminated milk can reach the consumer in case of inefficient pasteurization or when raw milk is used illegally for the production of Minas cheese or other dairy product. Lee (2003) suggested a possible transmission of Staph. aureus from cows to humans. Other studies refer higher prevalences of Staph. aureus or MSSA in milk samples (Coelho et al., 2009; D'Amico and Donnelly, 2010; Haran et al., 2012; Oikonomou et al., 2012).

The most prevalent spa types among our MSSA isolates from bovine sources were t127 and t605, and it is in accordance with previous reports from Brazil (Aires-de-Sousa et al., 2007; Rabello et al., 2007). In Canada, MSSA strains of lineage t605 were also observed (Said et al., 2010), whereas t127 isolates have been previously isolated from Switzerland and Korea (Huber et al., 2010; Hwang et al., 2010). Alternatively, other studies on milk samples from cows with mastitis showed Staph. aureus with different spa types to those detected among our MSSA isolates (Johler et al., 2011; Haran et al., 2012).

The database of the Ridom spa server network for spa typing (http://spaserver.ridom.de) shows that spa type t127 has a relative global frequency of $1.9 \%$ and t605

Table 3. Antibiotic resistance characteristics and spa types of the investigated methicillin-susceptible Staphylococcus aureus (MSSA) isolates according to the farm of origin

\begin{tabular}{|c|c|c|c|}
\hline Farm & $\begin{array}{l}\text { spa type of isolates } \\
\text { (no. of isolates) }\end{array}$ & 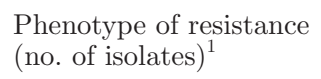 & $\begin{array}{l}\text { Resistance gene detected } \\
\text { (no. of isolates) }\end{array}$ \\
\hline I & - & - & - \\
\hline II & t2066 (1) & $\operatorname{STR}(1)$ & - \\
\hline III & t002 (1) & CHL (1), STR (1) & $\operatorname{fex} A^{2}(1)$ \\
\hline IV & $\mathrm{t} 127(5), \mathrm{t} 10856(1)$ & $\operatorname{STR}(2)$ & - \\
\hline V & $\mathrm{t} 127(1), \mathrm{t} 10852(1)$ & $\operatorname{STR}(1)$ & - \\
\hline VI & t605 (9), t1784 (1) & TET (1), STR (8) & $\operatorname{tet}(\mathrm{K})(1)$ \\
\hline VII & $\mathrm{t} 127(2), \mathrm{t} 10856(4)$ & STR (1) & - \\
\hline VIII & t127 (3) & $\operatorname{STR}(2)$ & - \\
\hline IX & t127 (3), t605 (9) & TET (1), STR (6) & $\operatorname{tet}(\mathrm{K})(1)$ \\
\hline $\mathrm{X}$ & t605 (3) & $\operatorname{TET}(1)$ & $\operatorname{tet}(\mathrm{K})(1)$ \\
\hline XI & t127 (11), t10856 (1) & $\operatorname{STR}(6)$ & - \\
\hline
\end{tabular}


of $0.1 \%$ (data collected in January 2013). Methicillinsusceptible Staph. aureus isolates with spa types t127 and 605 were distributed in almost all regions studied of the state of São Paulo, whereas those with spa type t10856 were found in 2 distinct regions (B and D). The 56 strains were distributed in 4 clonal complexes: CC1, CC5, CC126, and CC133. Among these, CC1 and CC126 were predominant. Rabello et al. (2007) observed the same clonal complexes in a study in Brazil from milk samples collected from cows with subclinical mastitis. The clonal complexes CC1 and CC5 are common among human isolates (Argudín et al., 2011; Lozano et al., 2012) and Juhász-Kaszanyitzky et al. (2007) reported strains of $\mathrm{CC} 1$ in humans and bovines. Franco et al. (2011) suggested that transmission of this lineage (CC1) from animals to humans is possible, although differences exist in the host-specific genetic characteristics between the 2 clusters. The clonal complex CC126 is not common among isolates from human beings and several studies observed this CC in ruminants (Smith et al., 2005; Aires-de-Sousa et al., 2007; Rabello et al., 2007), suggesting that ruminants are reservoirs for this CC.

The novel spa type t10856 belongs to CC133. Previous studies have reported the existence of $\mathrm{CC} 133$ in clinical Staph. aureus isolates from bovines (Rabello et al., 2007; Schlotter et al., 2012) and this lineage is very common in small ruminants (Guinane et al., 2010) and also in ungulates (Gharsa et al., 2012). It has been suggested that the CC133 clone is a result of a host jump from humans to these animals by an adaptive genome diversification from allelic variation, gene decay, and horizontal acquisition of mobile genetic elements containing virulence genes (Guinane et al. 2010).

The agr types I, II, and III were detected among our MSSA isolates, with agr types II and III the most frequently detected. Isolates of lineage ST1/CC1 were included in agr type III but 1 strain was included in agr type I.

The 4 virulence factors studied in this work (related to the Panton-Valentine leukocidin, toxic-shocksyndrome-toxin 1, and exfoliative toxin A and B) in MSSA isolates were negative. Nevertheless, these isolates could contain other virulence genes as is the case for enterotoxins (de Freitas Guimarães et al., 2013). A recent study showed Staph. aureus strains from milk from animals with mastitis with the $e t b$ gene encoding the exfoliative toxin B (Salasia et al., 2011).

Antibiotic susceptibility testing revealed that 27 of the 56 isolates (48.2\%) showed susceptibility to all antibiotics tested. Other studies reported susceptibility rates of $42 \%$ (Coelho et al., 2009) or 67\% (Aires-deSousa et al., 2007) among bovine Staph. aureus, the latter from farms located in Rio de Janeiro State. The detection in 1 isolate of the complete and conserved Tn558, which carries the chloramphenicol and florfenicol resistance gene fexA, is remarkable and, to the best of our knowledge, it represents the first description of this transposon in staphylococci in Brazil. Since its first description in a Staphylococcus lentus isolate from a cow with a respiratory tract infection (Kehrenberg and Schwarz, 2004), this transposon has been detected in Staphylococcus lentus simulans, Staphylococcus lentus chromogenes, and Staphylococcus lentus sciuri from bovines and in equine Staph. aureus isolates (Kehrenberg and Schwarz, 2006), Staphylococcus cohnii isolates from swine farms in China (Wang et al., 2012), and in Bacillus from swine feces (Dai et al., 2010). Further molecular epidemiological studies are required to assess the burden of this mobile genetic element among the Brazilian cow population. Interestingly, streptomycinresistant strains did not contain the expected resistance genes, suggesting the presence of mutations in specific ribosomal proteins or unknown resistance mechanisms to this antibiotic that should be characterized in the future.

\section{CONCLUSIONS}

Methicillin-susceptible Staph. aureus isolates were recovered in approximately $3.7 \%$ of milk samples tested, representing $57.7 \%$ of all Staph. aureus recovered. The major lineages detected among MSSA were CC126 and CC1, followed by the ruminant-associated CC133. In general, MSSA strains were susceptible to most antibiotics studied, although the detection of the conserved transposon Tn 558 evidences potential acquisition capacities. In spite of the absence of streptomycin resistance genes studied, $50 \%$ of MSSA strains were resistant to this antibiotic in the diffusion disk test, suggesting that other genes could be implicated. Due to the scarce data available on molecular characteristics of Staph. aureus isolates from cattle in Brazil, continued epidemiological surveillance is essential to gain knowledge on the circulating lineages responsible for cow mastitis in this major milk-producing country, due to its potential implications in both animal and human health.

\section{ACKNOWLEDGMENTS}

N. C. C. Silva has a fellowship from Coordenação de Aperfeiçoamento de Pessoal de Nível Superior (CAPES; Brazil; Process 9877-11-8), E. Gómez-Sanz has a predoctoral fellowship from the Gobierno de La Rioja (Spain), and D. Benito has a predoctoral fellowship from the Ministerio de Economía y Competitividad of Spain. Part of this work was financially supported 
by Project SAF2012-35474 from the Ministerio de Economía y Competitividad of Spain and the Fondo Europeo de Desarrollo Regional (FEDER).

\section{REFERENCES}

Aarestrup, F. M., Y. Agerso, P. Gerner-Smidt, M. Madsen, and L. B. Jensen. 2000. Comparison of antimicrobial resistance phenotypes and resistance genes in Enterococcus faecalis and Enterococcus faecium from humans in the community, broilers, and pigs in Denmark. Diagn. Microbiol. Infect. Dis. 37:127-137.

Aires-de-Sousa, M., C. E. S. R. Parente, O. Vieira-da-Motta, I. C. F. Bonna, D. A. Silva, and H. de Lencastre. 2007. Characterization of Staphylococcus aureus isolates from buffalo, bovine, ovine, and caprine milk samples collected in Rio de Janeiro state, Brazil. Appl. Environ. Microbiol. 73:3845-3849.

Argudín, M. A., M. C. Mendoza, F. Vázquez, B. Guerra, and M. R. Rodicio. 2011. Molecular typing of Staphylococcus aureus bloodstream isolates from geriatric patients attending a long-term care Spanish hospital. J. Med. Microbiol. 60:172-179.

Capurro, A., A. Aspán, U. H. Ericsson, W. K. Persson, and K. Artursson. 2010. Identification of potential sources of Staphylococcus aureus in herds with mastitis problems. J. Dairy Sci. 93:180-191.

Clark, N. C., Ø. Olsvik, J. M. Swenson, C. A. Spiegel, and F. C. Tenover. 1999. Detection of a streptomycin/spectinomycin adenylyltransferase gene (aadA) in Enterococcus faecalis. Antimicrob. Agents Chemother. 43:157-160.

CLSI (Clinical Laboratory Standards Institute). 2012. Performance Standards for Antimicrobial Susceptibility Testing. Nineteenth Informational Supplement. M100-S19. National Committee for Clinical Laboratory Standards, Wayne, PA.

Coelho, S. M. O., E. Reinoso, I. A. Pereira, L. C. Soares, M. Demo, C. Bogni, and M. M. S. Souza. 2009. Virulence factors and antimicrobial resistance of Staphylococcus aureus isolated from bovine mastitis in Rio de Janeiro. Pesquisa Veterinária Brasileira 29:369-374.

CRL-AR (Community Reference Laboratory for Antimicrobial Resistance). 2009: Multiplex PCR for the Detection of the mecA Gene and the Identification of Staphylococcus aureus. National Food Institute, Technical University of Denmark, Copenhagen, Denmark.

Dai, L., C-M. Wu, M.-G. Wang, Y. Wang, Y. Wang, S.-Y. Huang, L.-N. Xia, B.-B. Li, and J.-Z. Shen. 2010. First report of the multidrug resistance gene $c f r$ and the phenicol resistance gene fexA in a Bacillus strain from swine feces. Antimicrob. Agents Chemother. 54:3953-3955.

D'Amico, D. J., and C. W. Donnelly. 2010. Microbiological quality of raw milk used for small-scale artisan cheese production in Vermont: Effect of farm characteristics and practices. J. Dairy Sci. 93:134-147.

de Freitas Guimarães, F., D. B. Nóbrega, V. B. Richini-Pereira, P. M. Marson, J. C. de Figueiredo Pantoja, and H. Langoni. 2013. Enterotoxin genes in coagulase-negative and coagulase-positive staphylococci isolated from bovine milk. J. Dairy Sci. 96:28662872. http://dx.doi.org/10.3168/jds.2012-5864.

Francis, J. S., M. C. Doherty, U. Lopatin, C. P. Johnston, G. Sinha, T. Ross, M. Cai, N. N. Hansel, T. Perl, J. R. Ticehurst, K. Carroll, D. L. Thomas, E. Nuermberger, and J. G. Bartlett. 2005. Severe community-onset pneumonia in healthy adults caused by methicillin-resistant Staphylococcus aureus carrying the Panton-Valentine leukocidin genes. Clin. Infect. Dis. 40:100-107.

Franco, A., H. Hasman, M. Iurescia, R. Lorenzetti, M. Stegger, A. Pantosti, F. Feltrin, A. Ianzano, M. C. Porrero, M. Liapi, and A. Battisti. 2011. Molecular characterization of spa type t127, sequence type 1 methicillin-resistant Staphylococcus aureus from pigs. J. Antimicrob. Chemother. 66:1231-1235.

Gharsa, H., R. Ben Sallem, K. Ben Slama, E. Gómez-Sanz, C. Lozano, A. Jouini, N. Klibi, M. Zarazaga, A. Boudabous, and C. Torres. 2012. High diversity of genetic lineages and virulence genes in nasal Staphylococcus aureus isolates from donkeys destined to food consumption in Tunisia with predominance of the ruminant associated CC133 lineage. BMC Vet. Res. 8:203. http://dx.doi. org/10.1186/1746-6148-8-203.

Guinane, C. M., N. L. Ben Zakour, M. A. Tormo-Mas, L. A. Weinert, B. V. Lowder, R. A. Cartwright, D. S. Smyth, C. J. Smyth, J. A. Lindsay, K. A. Gould, A. Witney, J. Hinds, J. P. Bollback, A. Rambaut, J. R. Penadés, and J. R. Fitzgerald. 2010. Evolutionary genomics of Staphylococcus aureus reveals insights into the origin and molecular basis of ruminant host adaptation. Genome Biol. Evol. 2:454-466.

Halasa, T., K. Huijps, O. Østerås, and H. Hogeveen. 2007. Economic effects of bovine mastitis and mastitis management: A review. Vet. Q. 29:18-31.

Haran, K. P., S. M. Godden, D. Boxrud, S. Jawahir, J. B. Bender, and S. Sreevatsan. 2012. Prevalence and characterization of Staphylococcus aureus, including methicillin-resistant Staphylococcus aureus, isolated from bulk tank milk from Minnesota dairy farms. J. Clin. Microbiol. 50:688-695.

Huber, H., S. Koller, N. Giezendanner, R. Stephan, and C. Zweifel. 2010. Prevalence and characteristics of meticillin-resistant Staphylococcus aureus in humans in contact with farm animals, in livestock, and in food of animal origin, Switzerland, 2009. Euro Surveill. 15 :pii $=19542$.

Hwang, S. Y., Y. K. Park, H. C. Koo, and Y. H. Park. 2010. spa typing and enterotoxin gene profile of Staphylococcus aureus isolated from bovine raw milk in Korea. J. Vet. Sci. 11:125-131.

Jarraud, S., C. Mougel, J. Thioulouse, G. Lina, H. Meugnier, F. Forey, X. Nesme, J. Etienne, and F. Vandenesch. 2002. Relationships between Staphylococcus aureus genetic background, virulence factors, agr groups (alleles), and human disease. Infect. Immun. 70:631-641.

Johler, S., F. Layer, and R. Stephan. 2011. Comparison of virulence and antibiotic resistance genes of food poisoning outbreak isolates of Staphylococcus aureus with isolates obtained from bovine mastitis milk and pig carcasses. J. Food Prot. 74:1852-1859.

Juhász-Kaszanyitzky, E., S. Jánosi, P. Somogyi, Á. Dán, L. van der Graaf-van Bloois, E. van Duijkeren, and J. A. Wagenaar. 2007. MRSA transmission between cows and humans. Emerg. Infect. Dis. 13:630-632.

Kehrenberg, C., and S. Schwarz. 2004. fexA, a novel Staphylococcus lentus gene encoding resistance to florfenicol and chloramphenicol. Antimicrob. Agents Chemother. 48:615-618.

Kehrenberg, C., and S. Schwarz. 2005. Florfenicol-chloramphenicol exporter gene fexA is part of the novel transposon Tn558. Antimicrob. Agents Chemother. 49:813-815.

Kehrenberg, C., and S. Schwarz. 2006. Distribution of florfenicol resistance genes fexA and cfr among chloramphenicol-resistant Staphylococcus isolates. Antimicrob. Agents Chemother. 50:1156-1163.

Klein, R. C., M. H. Fabres-Klein, M. A. V. P. Brito, L. G. Fietto, and A. de Oliveira Barros Ribon. 2012. Staphylococcus aureus of bovine origin: Genetic diversity, prevalence and the expression of adhesinencoding genes. Vet. Microbiol. 160:183-188.

Kondo, Y., T. Ito, X. X. Ma, S. Watanabe, B. N. Kreiswirth, J. Etienne, and K. Hiramatsu. 2007. Combination of multiplex PCRs for staphylococcal cassette chromosome mec type assignment: Rapid identification system for mec, $c c r$, and major differences in junkyard regions. Antimicrob. Agents Chemother. 51:264-274.

Koneman, E. W., S. D. Allen, W. M. Janda, P. C. Schreckenberger, and W. C. Winn Jr. 2008. Diagnóstico Microbiológico-Texto e Atlas Colorido. 6th ed. Editora Guanabara Koogan, Rio de Janeiro, Brazil.

Lee, J. H. 2003. Methicillin (oxacillin)-resistant Staphylococcus aureus strains isolated from major food animals and their potential transmission to humans. Appl. Environ. Microbiol. 69:6489-6494.

Lina, G., Y. Piémont, F. Godail-Gamot, M. Bes, M.-O. Peter, V. Gauduchon, F. Vandenesch, and J. Etienne. 1999. Involvement of Panton-Valentine leukocidin-producing Staphylococcus aureus in primary skin infections and pneumonia. Clin. Infect. Dis. 29:1128-1132.

Lozano, C., N. Porres-Osante, J. Crettaz, B. Rojo-Bezares, D. Benito, I. Olarte, M. Zarazaga, Y. Sáenz, and C. Torres. 2013. Changes in genetic lineages, resistance, and virulence in clinical methicillin- 
resistant Staphylococcus aureus in a Spanish hospital. J. Infect. Chemother. 19:233-242. http://dx.doi.org/10.1007/s10156-0120486-4.

McDougall, S., K. Parker, C. Heuer, and C. Compton. 2009. A review of prevention and control of heifer mastitis via non-antibiotic strategies. Vet. Microbiol. 134:177-185.

Oikonomou, G., V. S. Machado, C. Santisteban, Y. H. Schukken, and R. C. Bicalho. 2012. Microbial diversity of bovine mastitic milk as described by pyrosequencing of metagenomic 16S rDNA. PLoS ONE 7: e47671.

Rabello, R. F., B. M. Moreira, R. M. M. Lopes, L. M. Teixeira, L. W. Riley, and A. C. D. Castro. 2007. Multilocus sequence typing of Staphylococcus aureus isolates recovered from cows with mastitis in Brazilian dairy herds. J. Med. Microbiol. 56:1505-1511.

Said, K. B., J. Ismail, J. Campbell, M. R. Mulvey, A. M. Bourgault, S. Messier, and X. Zhao. 2010. Regional profiling for determination of genotype diversity of mastitis-specific Staphylococcus aureus lineage in Canada by use of clumping factor A, pulsed-field gel electrophoresis, and spa typing. J. Clin. Microbiol. 48:375-386.

Salasia, S. I. O., S. Tato, N. Sugiyono, D. Ariyanti, and F. Prabawati 2011. Genotypic characterization of Staphylococcus aureus isolated from bovines, humans, and food in Indonesia. J. Vet. Sci. 12:353361 .

Santos, O. C. S., E. M. Barros, M. A. V. P. Brito, M. C. F. Bastos, K. R. N. Santos, and M. G. Marval. 2008. Identification of coagulasenegative staphylococci from bovine mastitis using RFLP-PCR of the groEL gene. Vet. Microbiol. 130:134-140.

Schalm, O. W., and D. O. Noorlander. 1957. Experimental and observation leading to development of California mastitis test. J. Am. Vet. Med. Assoc. 130:199-204.

Schlotter, K., R. Ehricht, H. Hotzel, S. Monecke, M. Pfeffer, and K. Donat. 2012. Leukocidin genes lukF-P83 and lukM are associated with Staphylococcus aureus clonal complexes 151, 479 and 133 isolated from bovine udder infections in Thuringia, Germany. Vet. Res. 43:42-49.
Schnellmann, C., V. Gerber, A. Rossano, V. Jaquier, Y. Panchaud, M. G. Doherr, A. Thomann, R. Straub, and V. Perreten. 2006. Presence of new mecA and $m p h(\mathrm{C})$ variants conferring antibiotic resistance in Staphylococcus spp. isolated from the skin of horses before and after clinic admission. J. Clin. Microbiol. 44:4444-4454.

Shopsin, B., B. Mathema, P. Alcabes, B. Said-Salim, G. Lina, A. Matsuka, J. Martinez, and N. Kreiswirth. 2003. Prevalence of agr specificity groups among Staphylococcus aureus strains colonizing children and their guardians. J. Clin. Microbiol. 41:456-459.

Smith, E. M., L. E. Green, G. F. Medley, H. E. Bird, L. K. Fox, Y H. Schukken, J. V. Kruze, A. J. Bradley, R. N. Zadoks, and C. G. Dowson. 2005. Multilocus sequence typing of intercontinental bovine Staphylococcus aureus isolates. J. Clin. Microbiol. 43:47374743.

Tenover, F. C., R. D. Arbeit, R. V. Goering, P. A. Mickelsen, B. E. Murray, D. H. Persing, and B. Swaminathan. 1995. Interpreting chromosomal DNA restriction patterns produced by pulsed-field gel electrophoresis: Criteria for bacterial strain typing. J. Clin. Microbiol. 33:2233-2239.

van Wamel, W. J. B., S. H. M. Rooijakkers, M. Ruyken, K. P. M. van Kessel, and J. A. G. van Strijp. 2006. The innate immune modulators staphylococcal complement inhibitor and chemotaxis inhibitory protein of Staphylococcus aureus are located on $\beta$-hemolysinconverting bacteriophages. J. Bacteriol. 188:1310-1315.

Wang, Y., W. Zhang, J. Wang, C. Wu, Z. Shen, X. Fu, Y. Yan, Q Zhang, S. Schwarz, and J. Shen. 2012. Distribution of the multidrug resistance gene cfr in Staphylococcus species isolates from swine farms in China. Antimicrob. Agents Chemother. 56:14851490.

Zafalon, L. F., A. Nader Filho, J. V. Oliveira, and F. D. Resende. 2007. Mastite subclínica causada por Staphylococcus aureus, custobenefício da antibioticoterapia de vacas em lactação. Arq. Bras. Med. Vet. Zootecn. 59:577-585. 